\title{
Poznawcze konsekwencje obrazu Boga i Jego wszechmocy w myśli Galileusza i Johannesa Keplera
}

Słowa kluczowe: Galileusz; Kepler; obraz Boga; omnipotencja

\section{Wprowadzenie}

Problem relacji nauki i religii doczekał się $\mathrm{w}$ historii nauki wielu interpretacji. Przełom antypozytywistyczny w humanistyce pozwolif dostrzec, że zagadnienia religijne czy teologiczne mogą mieć ważkie znaczenie dla interpretacji dorobku XVI- i XVII-wiecznych uczonych. Otworzyło to drogę do badania kulturowego kontekstu rozwoju nauki, w tym także wpływów o charakterze światopoglądowym. Badacze akcentowali konstruktywny wpływ na powstanie nauki nowożytnej biblijnej doktryny o stworzeniu ex nihilo oraz płynącego z niej obrazu Boga i Jego relacji do stworzenia, biblijnego dowartościowania pracy rąk ludzkich, średniowiecznej koncepcji racjonalności Boga, a także doktryn o Bożej wszechmocy i opatrzności². Wskazywano też, że

${ }^{1}$ Zakład Humanistycznych Nauk Wydziału Farmaceutycznego, Uniwersytet Medyczny Piastów Śląskich we Wrocławiu, e-mail: agnieszka.kazmierczak@umed.wroc. pl, ORCID: 0000-0003-3656-4951.

2 Por. R.K. Merton, Science, Technology and Society in Seventeenth Century England, „Osiris” 1938, vol. 4, s. 360-632; R. Hooykaas, Religia i powstanie nowożytnej nauki, tłum. S. Ławicki, Warszawa 1975; N.M. Wildiers, Obraz świata a teologia: od średniowiecza do dzisiaj, tłum. J. Doktór, Warszawa 1985; A. Funkenstein, Theology and the Scientific Imagination from the Middle Ages to the Seventeenth Century, Princeton 1986; God and Nature. Historical Essays on the Encounter between Christianity and Science, D.C. Lindberg, R.L. Numbers (red.), University of California Press, Berkley 
w pracach przyrodniczych Galileusza i Keplera znaleźć można motywację teologiczną ${ }^{3}$.

Celem niniejszego artykułu jest ukazanie znaczącej roli czynników światopoglądowych w kształtowaniu odmiennego obrazu świata w myśli Galileusza i Johannesa Keplera. Obaj uczeni, przyznając wysoki status matematyce, odmiennie ocenili możliwości, jakie daje ona w poznawaniu świata. Przyczynę takiego stanu rzeczy można upatrywać w odmiennych założeniach światopoglądowych. Zamierzam poddać analizie następujące kwestie: 1) w jaki sposób badani uczeni opisywali Boga i jego relację do Stworzenia? 2) Jak te poglądy wpływały na ich przekonania dotyczące możliwości poznawczych człowieka?

Metodologia zastosowana $\mathrm{w}$ artykule wykorzystuje ujęcie historyczno-kulturowe ${ }^{4}$. Zakładam, że uczeni konstruują pewną wizję świata, uznawaną przez nich za naturalną i rzeczywistą i do tej wizji dostosowują metody badania świata. Tworzone przez nich teorie naukowe odnoszą się do tego obrazu świata, a nie do świata bezpośred-

1986; J.H. Brooke, Science and Religion: Some Historical Perspectives, Cambridge 1991; Rethinking the Scientific Rewolution, M.J. Osler (red.), Cambridge 2000; P. Harrison, The Bible, Protestantism, and the Rise of Natural Science, Cambridge 1998.

${ }^{3} \mathrm{Na}$ temat teologicznych podstaw koncepcji przyrodniczych por. E.A. Burtt, Metaphysical Foundations of Modern Physical Science, London 1925, s. 44-95; W.L. Wisan, Galileo and God's Creation, „Isis” 1986, vol. 77, no. 3, s. 473-486; V.P. Remmert, Galileo, God, mathematics, [w:] Mathematics and the Divine. A Historical Study, T. Koetsier (red.), L. Bergmans, Elsevier 2005, s. 347-360; J.C. Pitt, Galileo, Human Knowledge and the Book of Nature, Dordrecht 1992, s. 1-23; D.B. Wilson, Galileo's Religion Versus the Church's Science? Rethinking the History of Science and Religion, „Physics in Perspective" 1999, no. 1, s. 65-84; A. Adamski, Galileusza filozofia i teologia nauki, Poznań 2002; J. Hübner, Die Theologie Johannes Keplers zwischen Orthodoxie und Naturwissenschaft, Tübingen 1975; J. Kozhamthadam, Religious Foundations of Kepler's Science, „Revista Portuguesa de Filosofia” 2002, vol. 58, s. 887-901; R. Martens, Kepler's Philosophy and the New Astronomy, Princeton 2000; P. Barker, B.R. Goldstein, Theological Foundations of Kepler's Astronomy, „Osiris” 2001, vol. 16, s. 88-113; A. Rothman, From Cosmos to Confession: Kepler and the Connection Between Astronomical and Religious Truth, [w:] Change and Continuity in Early Modern Cosmology, B.J. Boner (red.), Dordrecht 2011, s. 115-133.

${ }^{4}$ Inspiracje metodologiczne czerpałam z nieklasycznej historiografii nauki (tu szczególnie prace W. Wrzoska), z prac Ludwika Flecka, z konstruktywizmu historycznego i metodologii antropologii wiedzy proponowanej przez B. Płonkę-Syrokę. Por. W. Wrzosek, Historia-kultura-metafora. Powstanie nieklasycznej historiografii, Wrocław 1995; tenże, O myśleniu historycznym, Bydgoszcz 2009; Problemy wspótczesnej metodologii historii, tenże (red.), Bydgoszcz 2009; L. Fleck, Powstanie i rozwój faktu naukowego. Wprowadzenie do nauki o stylu myślowym i kolektywie myślowym, tłum. M. Tuszkiewicz, Lublin 1986; Ludwik Fleck - tradycje - inspiracje - interpretacje, B. Płonka-Syroka, P. Jarnicki, B. Balicki (red.), Wrocław 2015; Horyzonty konstruktywizmu. Inspiracje, perspektywy, przyszłość, E. Bińczyk, A. Derra, J. Grygieńć (red.), Toruń 2015; B. Płonka-Syroka, Medycyna w historii i kulturze, Wrocław 2016. 
Poznawcze konsekwencje obrazu Boga i Jego wszechmocy...

nio. Dlatego uznaję, że nie można rozpatrywać poglądów naukowych w oderwaniu od całokształtu kultury.

\section{Doktryna o wolnym stworzeniu świata i Boskiej wszechmocy}

Michael B. Foster zwrócił uwagę w 1934 r., że założenie biblijne o wolnym stwórczym akcie Boga implikuje przyjęcie twierdzenia o przygodności bytów stworzonych, które mogą być poznawane na drodze empirycznej5. W późniejszych latach tezę tę rozwinęli inni badacze $^{6}$, którzy zwracali uwagę, że woluntaryzm w teologii częściej łączył się z empiryzmem $\mathrm{w}$ badaniach, a intelektualizm wiązany był raczej z racjonalizmem. Teologowie średniowieczni próbowali zinterpretować relacje Boskiej woli i intelektu' ${ }^{7}$. Woluntaryści w zakresie moralności wierzyli, że to, co Bóg uzna za dobre, jest dobre, podczas gdy intelektualiści twierdzili, że Bóg ze względu na swą dobroć może za takie uznać tylko rzeczy dobre. W filozofii przyrody natomiast pojawiały się pytania, czy Bóg może uczynić wszystko to, co chce, czy może jest ograniczony przez naturę rzeczy. Woluntaryści akcentowali wagę Boskiej woli, niezdeterminowanej przez rozum, a także Bożą wszechmoc, podczas gdy intelektualiści podkreślali, że stworzenie było aktem doskonałego rozumu. Stąd też ludzkim umysłem możemy poznawać rozumną i konieczną naturę wszechświata. Dla woluntarystów taka droga poznania była nie do zaakceptowania. W ich ujęciu

${ }^{5} \mathrm{~W}$ przeciwieństwie do tego stworzenie świata w ujęciu filozofów greckich Platona i Arystotelesa nie było dziełem niezależnego twórcy. Świat oraz twórca byli podporządkowani pewnym regułom. W tej sytuacji poznanie tych reguł było możliwe za pomoca rozumu. Por. M.B. Foster, The Christian Doctrine of Creation and the Rise of Modern Natural Science, „Mind” 1934, vol. 43, no. 172, s. 464.

${ }^{6}$ Por. F. Oakley, Christian Theology and the Newtonian Science: The rise of the concept of laws of nature, „Church History” 1961, vol. 30, no. 4, s. 433-457; E.M. Klaaren, Religious Origins of Modern Science, Grand Rapids 1977; M. Osler, Divine will and the mechanical philosophy: Gassendi and Descartes on contingency and necessity in the created world, Cambridge 1994. W ostatnich latach na trudności związane z tezą zwrócił uwagę P. Harrison w: Voluntarism and Early Modern Science, „History of Science” 2002, vol. 40, s. 63-79. Por. też: J. Henry, Voluntarist Theology at the Origins of Modern Science: A Response to Peter Harrison, „History of Science” 2009, vol. 47, no. 1, s. 79-113; F. Oakley, Voluntarist Theology and early-modern science: The matter of the divine power, absolute and ordained, „History of Science”, https://doi. org/10.1177/0073275317722241 (dostęp: 6.01.2018).

7 Teologowie różnie odnosili się do relacji Boskiego rozumu i woli. Zbytnie akcentowanie roli Boskiego intelektu zostało potępione w 1277 r. przez biskupa paryskiego Étienne'a Tempiera, co zaowocowało w późniejszym okresie koncepcjami J. Buridana, M. Oresme czy W. Ockhama. 
możliwe jest tylko poznanie a posteriori. Woluntaryści ponadto mieli silniej akcentować całkowitą zależność stworzenia od Stwórcy ${ }^{8}$.

Jak wskazuje Christopher Kaiser, ok. XI-XII w. sformułowano rozróżnienie między regularną, uporządkowaną mocą Bożą (potentia ordinata), odnoszoną do naturalnego porządku, a absolutną mocą Bożą (potentia absoluta), dzięki której Bóg mógł zawiesić lub zmienić porządek przyrody. Teologowie scholastyczni próbowali pogodzić w ten sposób wszechmoc Boga z obserwowaną regularnością praw natury. Nadmierne akcentowanie potentia ordinata mogło sugerować, że prawa natury działają niezależnie lub automatycznie, odkąd zostały ustanowione. Dlatego część teologów podkreślała rolę potentia absoluta, w ramach której Bóg zawieszał porządek naturalny, np. przez cuda. Obie koncepcje ustanawiały odmienne relacje między Bogiem a człowiekiem i światem i wskazywały na różne rozumienie Bożej opatrzności ${ }^{9}$.

Tezy woluntarystyczne miały być podjęte przez reformatorów protestanckich, którzy akcentowali prymat Bożej woli, całkowitą i bezpośrednią zależność stworzenia od Stwórcy, a także nieustanne działanie Bożej opatrzności. Stąd też woluntaryzm częściej łączono z uczonymi protestanckimi, choć wielu katolików podzielało podobne poglądy (jak np. Gassendi czy Descartes), a niektórzy luteranie prezentowali stanowisko intelektualistów (np. Leibniz). Jak pokazuje Peter Harrison, w omawianym okresie wszyscy chrześcijanie zgadzają się co do tego, że Bóg podtrzymuje świat $w$ istnieniu ${ }^{10}$. Różnice dotyczyły raczej charakteru tego działania, a poszczególni uczeni, z różnych kręgów wyznaniowych, tworząc własne obrazy świata, sytuowali je w odpowiedniej relacji do Boga.

\section{Obraz Boga i Jego wszechmocy w myśli Galileusza}

Galileusz (1564-1642) wychowany był w kręgu religii katolickiej. Miał pewną wiedzę teologiczną, choć nie był profesjonalnym teologiem. Spór, jaki uczony wiódł z Kościołem katolickim, inspirował pytania o jego wiarę. Wielu badaczy zwraca uwagę, że był szczery w swoich deklaracjach dotyczących wiary ${ }^{11}$, a gorliwość wobec Kościoła stanowiła ważny motyw działania ${ }^{12}$.

${ }^{8}$ J. Henry, Religion and the Scientific Revolution, [w:] Cambridge Companion to Science and Religion, P. Harrison (red.), Cambridge 2010, s. 48-50.

${ }^{9}$ Ch. Kaiser, Creation and the History of Science, London 1991, s. 30, 131.

${ }^{10}$ P. Harrison, Voluntarism and Early..., dz. cyt., s. 5-9.

11 O. Pedersen, Wiara Galileusza, [w:] Sprawa Galileusza, tłum. M. Olszańska, K. Sławińska, A. Szostkiewicz, J. Życiński (red.), Kraków 1991, s. 149-191; J.J. Langford, Galileo, Science and the Church, Michigan 1992, s. 180.

${ }_{12}$ Przekonuje o tym jeden z czołowych biografów Galileusza S. Drake w książce Galileo. A Very Short Introduction, Oxford 2001. 
Galileusz poruszał wątki teologiczne pobocznie (z wyjątkiem kwestii interpretacji Pisma Świętego), obok rozważań dotyczących problemów przyrodniczych. Boga przedstawiał jako życzliwego Stwórcę. W tekstach padają określenia „boski Budowniczy”13, „źródło wszelkich dóbr" ${ }^{14}$ i podkreślane są atrybuty Boga, szczególnie dobroć i nieskończona mądrośćc ${ }^{15}$. W ujęciu uczonego Bóg stworzył świat przy użyciu systemu matematycznego. Jak pisze w często przywoływanym fragmencie na temat wszechświata: „księga ta została napisana w języku matematyki, i jej literami są trójkąty, koła i inne figury geometryczne" ${ }^{16}$. Świat był więc uporządkowany ${ }^{17}$. Bóg, tworząc go, narzucił określone prawa przyrodzie, a ona „najdoskonalej zachowuje Boże rozporządzenia”, a „[...] będąc nieubłaganą i niezmienną i nigdy nie przekraczając granic nadanych jej praw, jak gdyby nie troszczy się o nic więcej, jak tylko o swoje ukryte racje i sposoby działania, niezależnie od tego czy są one zrozumiałe przez człowieka, czy też nie" ${ }^{18}$. Galileusz pisze wprost o mądrości w działaniu natury, co jest konsekwencją mądrości Stwórcy ${ }^{19}$, który objawia się zarówno w Piśmie Świętym, jak i w naturze ${ }^{20}$.

Stworzenie świata dało początek relacji Boga do Jego dzieła. Galileusz akcentuje relatywną autonomię natury i zakłada, że Bóg (jako pierwsza przyczyna) w akcie stwórczym narzucił jej prawa, których ona przestrzega (stając się przyczyną wtórną zjawisk). Uczony podziela w ten sposób idee wypracowane w epoce średniowiecznej ${ }^{21}$.

${ }^{13}$ Galileusz, Dialog o dwóch najważniejszych układach świata: ptolemeuszowym $i$ kopernikowym, tłum. E. Ligocki, Warszawa 2004, s. 41.

${ }_{14}$ Takie sformułowanie pada $\mathrm{w}$ liście dedykacyjnym skierowanym do księcia Kosmy II Medyceusza (1590-1621) w pracy Sidereus nuncius, tłum. A. Pacewicz, Wrocław 2010, s. 29.

${ }^{15}$ Por. Galileusz, Dialog o dwóch najważniejszych..., dz. cyt., s. 154-155; tenże, List do Księżnej Krystyny, [w:] A. Adamski, dz. cyt., s. 114.

${ }_{16}$ Tenże, Waga probiercza, tłum. T. Sierotowicz, Kraków-Tarnów 2009, s. 55.

17 Podkreśla to np. w Dialogu o dwóch najważniejszych..., dz. cyt., s. 24.

${ }^{18}$ Galileusz, List do Księżnej Krystyny, [w:] A. Adamski, dz. cyt., s. 114.

${ }^{19}$ Por. Dialog o dwóch najważniejszych..., dz. cyt., s. 154.

${ }^{20}$ Kwestia ta często była podejmowana przez uczonych nowożytnych, chętnie posługujących się patrystycznym rozróżnieniem dwóch ksiąg: Pisma i Natury. Galileusz podejmuje te wątki szczególnie w Liście do Księżnej Krystyny..., dz. cyt., a ciekawie ujmuje to w Liście do o. Benedetto Castellego z 21 grudnia 1613 r., pisząc, że: „Pismo Święte, jak i przyroda w równym stopniu pochodzą od słowa Bożego”. Por. tenże, Listy kopernikańskie, tłum. T. Sierotowicz, Tarnów 2006, s. 34.

${ }^{21} \mathrm{~W}$ okresie średniowiecznym panowała zgoda co do tego, że Bóg może działać pośrednio przez przyczyny wtórne, jak planety czy aniołowie, a także w sposób bezpośredni. Zarówno regularny rytm przyrody, jak i „naruszenie” tego rytmu (rozumiane jako cuda) było wynikiem Bożej opatrzności. Por. M. Wildiers, Obraz świata i teologia, tłum. J. Doktór, Warszawa 1985, s. 23-89. 
W Dialogu o dwóch najważniejszych układach świata (1632) możemy znaleźć rozważania o Bożej wszechmocy oraz o zakresie jej działania. Galileusz zakłada, że Bóg i przyroda działają w sposób najprostszy. W słowach Salviatiego stwierdza: „kto chciałby uwierzyć, że natura (wedle powszechnie uznanej zasady nie posiłkująca się mnogimi środkami tam, gdzie wystarcza ich niewiele) obrała drogę wprowadzenia bezmiernej liczby olbrzymich ciał w ruch, o nieobliczalnie wielkiej prędkości, by dojść do tego samego, co można osiągnąć umiarkowanym ruchem jednego ciała, obracającego się naokoło swego własnego środka?"22. Poszukiwanie w naturze matematycznej prostoty zjawisk przekonywało Galileusza o prawdziwości konkretnych teorii. Przeciwnicy kopernikanizmu formułowali argument, że dla Boga nie ma rzeczy niemożliwych, gdyż Jego moc jest nieskończona. Tego typu argument wysunął też papież Urban VIII, a Galileusz zamieścił go w zakończeniu swojego tekstu w ustach Simplicia - karykaturalnego bohatera, prezentującego skostniałe poglądy Perypatetyków. Warto zwrócić uwagę, że polemika dotyczy rozumienia Bożej wszechmocy i charakteru Jego opatrzności. Galileusz stwierdza, że Bóg podtrzymuje świat przede wszystkim przez regularne działanie natury. Salviati, tłumacząc, w jaki sposób w przyrodzie następuje nadanie odpowiedniej prędkości ciału będącemu w spoczynku, mówi „Ja nie powiedziałem i nie śmiałbym twierdzić, że dla natury i Boga byłoby niemożliwe nadanie takiej, jak mówicie prędkości, i to natychmiast. Twierdzę jedynie, że de facto natura tego nie czyni. Takie rozwiązanie stałoby poza naturalnym biegiem rzeczy, a więc należałoby do dziedziny cudów”23. Galileusz w Dialogu kilkukrotnie odpiera zarzuty o to, że ogranicza moc Boga, która jest nieskończona, przez co Bóg może działać wbrew prawom przyrody i m.in. wprowadzić w ruch cały wszechświat, aby krążył wokół Ziemi. Oponenci Galileusza podkreślali, że dla nieograniczonej mocy Boga jest to proste. Autor w odpowiedzi podkreśla, że moc Boga jest nieskończona, a „w nieskończoności jedna część nie jest większa od innej części, jeżeli obie są skończone" ${ }^{24}$. Dlatego też to, że Bóg posłużył się „prostszym” rozwiązaniem, w żaden sposób nie świadczy o tym, że Jego moc jest ograniczona.

Galileusza zakłada, że jest pewien naturalny porządek, o charakterze matematycznym, zaplanowany i stworzony przez Boga. Nie zaprzecza, że Bóg mógłby go przekroczyć (akcentując moc absolutną),

\footnotetext{
${ }^{22}$ Galileusz, Dialog o dwóch najważniejszych..., dz. cyt., s. 178, 189.

23 Tamże, s. 28.

${ }^{24}$ Tamże, s. 188.
} 
lecz uważa, że Bóg tego nie robi - sam ogranicza swoją moc do podtrzymywania świata w jego naturalnym biegu. Galileusz sprzeciwia się tu woluntarystycznemu stanowisku Urbana VIII, wskazując, że Bóg, stwarzając świat, posłużył się matematycznym planem i w jego ramach działa, tym samym uczony sytuuje się na stanowisku teologicznym intelektualistów. Bóg stworzył świat przyrody, który wyposażył w określone prawa, podtrzymuje go $\mathrm{w}$ istnieniu, lecz pozostawia mu autonomię.

\section{Obraz Boga i Jego wszechmocy w myśli J. Keplera}

J. Kepler (1571-1630), wychowany w rodzinie luterańskiej, ukończył studia teologiczne w Tybindze, lecz zrezygnował z planów zostania pastorem i zajął się nauczaniem matematyki w szkole w Grazu. W jego pismach wielokrotnie pojawiają się odwołania do poglądów religijnych. Nie ma wątpliwości wśród badaczy, że był człowiekiem szczerze religijnym. Kepler nie tylko był wykształcony teologicznie, ale myślał teologicznie, także w kwestiach naukowych ${ }^{25}$.

Johannes Kepler w swoich pismach wielokrotnie odnosi się do Boga, sławiąc Jego wielkość, mądrość, dobroć czy wszechmoc, i do takiej chwały zachęcając innych ${ }^{26}$. Przyjmuje chrześcijańską doktrynę o stworzeniu świata przez Boga ex nihilo ${ }^{27}$. Pisze w Tajemnicy kosmosu (1596), że „Bóg, niby jeden z naszych architektów, przystąpił do kształtowania świata według porządku i zasady, i wymierzył wszystkie szczegóły”28. Bóg miał posłużyć się pewnymi regułami przy procesie stwórczym. W Tajemnicy kosmosu, stanowiącej wczesny wykład jego myśli, przyjmuje, że Bóg posłużył się bryłami foremnymi, stwarzając wszechświat. Pogląd ten podtrzymany zostaje później, lecz Kepler wskazuje, że reguł stwórczych dostarczyła geometria ${ }^{29}$. Z teologicz-

${ }^{25}$ E.W. Gerdes, Johannes Kepler as Theologian, „Vistas in Astronomy” 1975, vol. 18, s. 339-367.

${ }^{26}$ Kepler zamieszcza fragmenty sławiące szczególnie Boga jako Stwórcę, w których wychwala wielkość, potęgę i piękno Jego dzieła. Do takiego działania zachęca też innych, wskazując, że jest to właściwy cel prowadzenia badań. We wstępie do Astronomia nova (1609) udziela rady astronomom, aby nie zapomnieli o boskiej dobroci okazywanej człowiekowi i sławili dzieła Stwórcy, nie tylko wychwalając „dobroczynność Boskiego Stwórcy, w Jego trosce o dobro wszystkich żywych istot, wyrażonej w trwałości i stabilności Ziemi, ale także uznajcie Jego mądrość w jej ruchu, tak dobrze ukrytą i tak godną podziwu”. Zob. Johannes Kepler Gesammelte Werke (dalej JKGW), M. Caspar, W. Von Dyck (red.), Bd. 3, s. 33.

${ }^{27}$ J. Kepler, Tajemnica kosmosu, tłum. M. Skrzypczak, E. Zakrzewska-Gębka, Warszawa 2003, s. 9.

${ }^{28}$ Tamże s. 8.

${ }^{29}$ Por. tamże, s. 25; w Harmonii świata w ks. V omawia krótko kwestię brył foremnych, a także w Epitome Astronomiae Copernicanae w ks. IV. 
nego punktu widzenia konieczne było, aby owe zasady geometryczne nie były czymś od Boga niezależnym, jak miało to miejsce w tradycji platońskiej. Kepler precyzuje swój pogląd na stworzenie w księdze IV Harmonii świata (1619), stwierdzając, że geometria była współwieczna z umysłem Boga (a tym samym należy do istoty Boga) i dostarczyła wzorca dla stworzenia ${ }^{30}$. Takie rozwiązanie, przyjęte przez Keplera, sugeruje, że Bóg, stwarzając świat, był „ograniczony” ideami geometrycznymi, które były współwieczne z nim.

Rozwiązanie Keplera jest zbliżone do ujęcia Augustyna, który umieścił idee rzeczy stworzonych w Bożym umyśle. Bóg odwiecznie widział je w sobie jako możliwe odbicia samego siebie. Stworzenia stanowiły przykład modelu obecnego w Bożym umyśle. Wprowadził teorię „racji zarodkowych” (rationes seminales), stanowiących niewidzialne siły, dążące do samorozwoju, które w określonym czasie rozwijają się w przedmioty danego gatunku, zgodnie z Bożym planem, choć potrzebują do tego właściwych warunków. Taka koncepcja uwypuklała Boże sprawstwo i umniejszała przyczynowe działanie stworzeń. Augustyn dążył do podkreślenia absolutnego zwierzchnictwa Boga, całkowitej zależności świata od Niego, a także skończonej natury stworzeń wobec nieskończonego Stwórcy ${ }^{31}$. Jak wskazuje F. Copleston, „racje zarodkowe” są utożsamiane z liczbami, w ten sposób idee byłyby liczbami ukrytymi, a ciała liczbami uzewnętrznionymi ${ }^{32}$. Podobną interpretację sugeruje A. Siemieniewski, wskazując, że Augustyn traktuje porządek matematyczny jako uprzedni wobec świata materialnego, matematyka była więc wzorcem dla Bożego stworzenia ${ }^{33}$.

Świat w ujęciu Keplera stanowił materialny obraz Boga. W Jego umyśle miały być obecne matematyczne harmonie, stanowiące przyczynę, dla której zjawiska są takie, jakie są. W Epitome Copernicane Astronomiae w Księdze IV Kepler, odwołując się do sfery niebieskiej,

${ }^{30}$ The Harmony of the World by Johannes Kepler, trans. E.J. Aiton, A.M. Duncan, J.V. Field, Philadelphia 1997, s. 304.

${ }^{31}$ F. Copleston, Historia filozofii, Tom II. Od Augustyna do Szkota, tłum. S. Zalewski, Warszawa 2000, s. 86-87, 90-92.

32 Tamże, s. 92-93.

${ }_{33}$ A. Siemieniewski, Ścieżka nauki do Boga. Nauki przyrodnicze i duchowość w starożytności i średniowieczu, Warszawa 2009, s. 173-176. Stanowisko Augustyna inspirowało symboliczne odczytanie świata w okresie średniowiecza, a później miało wpływ na rozwój hermetyzmu w dobie renesansu i we wczesnej nowożytności. Por. Z. Liana, Inspiracje chrześcijańskie w rozwoju myśli naukowej, [w:] Nauki przyrodnicze a teologia: konflikt $i$ wspótistnienie, M. Heller, Z. Liana, J. Mączka, W. Skoczny (red.), Tarnów 2001, s. 80-81. 
wskazuje, że jest ona obrazem Boga Stwórcy i Archetypu świata ${ }^{34}$. Jak sugeruje R. Martens, harmonie odkrywane w obserwowanych faktach miały stanowić ich przyczynę formalną i celową ${ }^{35}$. Takie ujęcie wiąże się z teologicznym przekonaniem Keplera, że Bóg stworzył świat w zgodzie z zasadą doskonałych liczb ${ }^{36}$. Wydaje się, że uczony uznawał realne istnienie owych wzorców. Ciekawy przykład stanowi tu traktat Keplera Noworoczny podarek albo o sześciokatnych ptatkach śniegu (1611), w którym wskazuje on na uniwersalność pierwotnego wzoru w świecie: „przyczyna kształtu sześciokątnych płatków śniegu nie różni się od przyczyny stojącej za uporządkowanymi kształtami roślin i liczbami stałymi. A skoro w nich nic nie dzieje się bez najwyższej przyczyny - nie mówię tu o tych rzeczach, które można odkryć za pomocą rozumowania, ale o tych, które od początku były w zamysłach Stwórcy i zostały zachowane aż do teraz przez zadziwiającą naturę zdolności zwierząt - nie wierzę, by nawet w płatku śniegu uporządkowany kształt istniał bez przyczyny" ${ }^{37}$.

Kepler w swoich pracach stosuje pojęcie archetypu przede wszystkim na określenie planu, który znajdował się w umyśle Boga i stanowił podstawe struktury świata fizycznego. Poznanie świata oznaczało dotarcie do archetypicznej struktury kosmosu ${ }^{38}$. Z czasem uczony doszedł do wniosku, że archetypiczny wzór urzeczywistnia się także w świecie ziemskim. Nie jest do końca jasne, jak sobie to wyobrażał. Pewien wpływ mogły mieć (stanowiące przyczynę sprawczą) zdolności ożywiające (facultas animalis), którymi Kepler obdarzył różne elementy świata przyrodniczego ${ }^{39}$. Dusza Ziemi miała ogromne znaczenie w urzeczywistnianiu się archetypów i stanowiła „podstawę” dla podobnych zdolności $\mathrm{w}$ innych obiektach ${ }^{40}$. Wątki animistyczne

${ }^{34}$ J. Kepler, Epitome of Copernican Astronomy and Harmonies of the World, ttum. Ch.G. Wallis, Amherst N.Y. 1995, s. 13.

${ }_{35}$ R. Martens, dz. cyt., s. 39.

${ }^{36}$ Widać tu wyraźne wpływy pitagoreizmu, jednak uczony nie zatrzymał się na estetycznej kontemplacji geometrycznych relacji. Por. na ten temat E.A. Burtt, dz. cyt., s. 53-54.

${ }_{37}$ J. Kepler, Noworoczny podarek albo o sześciokątnych płatkach śniegu, tłum. D. Sutkowska, Warszawa 2006, s. 64.

38 Por. J. Włodarczyk, Astrologia. Historia. Mity. Tajemnice, Warszawa 2008, s. $243-244$.

${ }^{39}$ P.J. Boner, Kepler's Living Cosmology: Bridging the Celestial and Terrestrial Realms, „Centaurus” 2006, vol. 48, s. 32-39.

${ }^{40}$ W Noworocznym podarku..., dz. cyt. (s. 65) tak uczony opisuje to zjawisko „Przyjmijmy, że każda roślina ma własną zdolność; ale wszystkie te zdolności są potomstwem jednej i tej samej ogólnej zdolności, która jest w Ziemi [...] Zdolność Ziemi, która sama z siebie jest jedna i ta sama, dzieli się na ciała i wraz z ciałami, wrasta w nie i stosownie do wewnętrznego stanu każdej materii albo zewnętrznych uwarunkowań buduje za każdym razem coś innego". 
łączyły się z mechanicznymi, a świat Keplera wymyka się podziałom na organiczny i mechaniczny.

Poszukiwanie porządku i harmonii również było motywowane religijnie $^{41}$. Harmonia w świecie była odbiciem Boga. Ujawnianie matematycznych harmonii stało się celem pracy i stanowiło pełniejsze poznanie Boga przez naturę. Daje temu wyraz w Księdze III Harmonii świata, pisząc, że geometria, będąc współwieczną z Bogiem, dostarczyła wzorca do stworzenia świata najlepszego, najpiękniejszego i najbardziej podobnego Stwórcy ${ }^{42}$. Kepler odrzucał możliwość działania przypadkowych sił we wszechświecie. To, co się działo, musiało być zgodne z pewnym porządkiem. P. Barker i B. Goldstein wskazują, że Filip Melanchton w XVI w. podkreślał, że odkrywany w przyrodzie porządek i pewien wzór świadczy o istnieniu życzliwego Stwórcy, a Kepler według wspomnianych autorów miał ten pogląd podzielać ${ }^{43}$. Wydaje się jednak, że korzeni takiego ujęcia należy poszukiwać wcześniej - w myśli Augustyna.

Kepler ponadto wierzył w Boga Trójjedynego, którego geometryczną reprezentację można znaleźć w świecie, co przedstawił m.in. w Tajemnicy kosmosu, gdzie słońce stanowiło alegorię Boga Ojca, Syn Boży odpowiadał sferze gwiazd stałych, a Duch Święty przestrzeni pośredniej ${ }^{44}$.

Uczony, przyjmując koncepcje archetypicznej struktury świata, nie chciał, aby stworzony przez niego obraz świata był niezależny od Boga. Teologie reformowane podkreślały wówczas aktywność Boga i całkowitą zależność stworzenia od Stwórcy nie tylko w porządku zbawienia, ale także $\mathrm{w}$ przyrodzie ${ }^{45}$. Kepler stanowisko to podziela i akcentuje konieczność Bożej aktywności w świecie. W Harmonii świata w księdze IV, tłumacząc funkcjonowanie natury, wskazuje na rolę duszy Ziemi, którą opisuje jak płomień. Jest ona aktywna, lecz ta aktywność pochodzi od Boga. Bóg bowiem podtrzymuje ten płomień. Bez Bożej aktywności płomień zgasłby ${ }^{46}$.

${ }^{41}$ Zwraca na to uwage Kepler w wielu swoich pracach, np. kończąc traktat Tajemnica kosmosu, wskazuje, że celem poznania planu Stwórcy powinno być Jego uwielbienie, uczczenie i umiłowanie. Por. J. Kepler, Tajemnica..., dz. cyt., s. 213.

42 „The Harmony of the World..., dz. cyt., s. 146. Podobne myśli wyraża także w Epitome..., dz. cyt., pisząc, że Bóg objawia się w Księdze Natury i zawarł w niej swą istotę i swą wolę. Por. JKGW, t. 7, s. 25.

43 P. Barker, B.R. Goldstein, dz. cyt., s. 93-97.

44 Wczesny entuzjazm Keplera wobec kopernikanizmu był wiązany z rolą słońca, którą ujął teologicznie. Por. J. Kozhamthadam, dz. cyt., s. 891. W późniejszym okresie takie ujęcie pojawia się także, np. w ks. IV Epitome..., dz. cyt.

45 G.B. Deason, Reformation Theology and the Mechanistic Conception of Nature, [w:] God and Nature. Historical Essays on the Encounter between Christianity and Science, D.C. Lindberg, R.L. Numbers (red.), Berkeley 1986, s. 167-191.

46 The Harmony of the World..., dz. cyt., s. 367. 
Podejście Keplera do zagadnień związanych z aktywnością Boga w świecie ukazuje jego wymiana listów z Davidem Fabriciusem (1564-1617) oraz dzieło De stella nova (1606), w którym znajdujemy interpretację uczonego na temat pojawienia się nowej gwiazdy w 1604 r. Kepler odrzuca czysto teologiczną interpretację Fabriciusa ze względów zarówno fizycznych, jak i teologicznych. Jednocześnie poszukuje naturalnego wytłumaczenia dla pojawienia się gwiazdy. W tym samym roku nastąpiło także inne niezwykłe zjawisko astronomiczne - koniunkcja trzech planet: Jowisza, Saturna oraz Marsa. Kepler sugerował, że te dwa zjawiska naraz wymagają działania „boskiego architekta" ${ }^{47}$. Miguel Granada, analizując spór z Fabriciusem, wskazuje, że Kepler obok wskazania naturalnych przyczyn takiego zjawiska dodaje jego teologiczną interpretację. To Bóg posługuje się naturą, która mu służy, aby oba zdarzenia wystąpiły w tym samym czasie. Jest to więc wynik opatrznościowego działania Boga, który realizuje swój zbawczy plan wobec człowieka ${ }^{48}$. Kepler jest daleki od przyjmowania czysto teologicznych wyjaśnień zjawisk. Poszukuje naturalnych przyczyn zdarzeń, jednak zakłada stałe podtrzymywanie świata przez Boga, który działa w nim aktywnie.

\section{Poznawcze konsekwencje odmiennych założeń teologicznych dotyczących Boga, natury i człowieka}

\section{Galileusz}

Jak podkreślono $\mathrm{w}$ jednym $\mathrm{z}$ poprzednich podrozdziałów, przyroda, w myśli Galileusza, stworzona z pomocą systemu matematycznego, przestrzega danych jej przez Stwórcę praw. Człowiek, stworzony przez Boga, ma odpowiednie zdolności do poznania przyrody. Pisząc w Liście do Krystyny Lotaryńskiej na temat autorytetu Pisma Świętego, zauważa: „ten sam Bóg, który wyposażył nas w możliwość mówienia i rozumienia, założył korzystanie $\mathrm{z}$ nich, więc tym samym dał nam możliwość zdobywania wiedzy innymi środkami. Zatem prawda objawia się naszym oczom i intelektowi także we wnioskach naturalnych, do których dochodzimy na podstawie doświadczeń zmysłowych lub niezbitych dowodów[...]"49. Nie korzystając z tych możliwości, „poniżamy naszą kondycję, co nie pozostaje bez obrazy naszej natury,

\footnotetext{
${ }^{47}$ J. Kepler, De stella nova serpentarii, [w:] JKGW, t. 1, s. 290.

${ }^{48}$ M.A. Granada, Johannes Kepler and David Fabricius: Their Discussion on the Nova of 1604, [w:] Change and Continuity..., dz. cyt., s. 77-79.

${ }^{49}$ Galileusz, List do Księżnej Krystyny..., dz. cyt., s. 114-115.
} 
i [...] Bożej Dobroci" ${ }^{50}$. Galileusz jest przekonany, że prawdy zawarte w dwóch księgach Pisma i Przyrody muszą być zgodne, lecz to ta druga księga może rzucić światło na interpretacje spornych fragmentów Pisma Świętego dotyczących głównie obrazu świata ${ }^{51}$.

Kluczowa w poznaniu przyrody jest rola matematyki, a bez jej znajomości „udziałem człowieka jest próżne błąkanie się po ciemnym labiryncie" 52 . Prawda o naturze składa się z faktów matematycznych, które są realne i mierzalne. Natura wyraża się ilościowo, a wszelkie jakościowe aspekty pochodzą z zewnątrz - z ludzkiego umysłu. Zrozumienie roli matematyki $\mathrm{w}$ jego obrazie natury jest bardzo ważne. Czy struktura świata jest matematyczna, czy może natura wyraża się w sposób matematyczny i nauka ta jest raczej sposobem poznawania świata? Wydaje się, że to drugie twierdzenie jest mu bliższe ${ }^{53}$. Tym bardziej że Galileusz wskazywał, iż możemy poznać tylko pewne własności substancji, a nie ją samą. „Poszukiwanie zaś substancji obiektów przyrodniczych mam za przedsięwzięcie niemożliwe i będące stratą energii, tak jeśli chodzi o obiekty blisko położone, jak i te bardzo odległe i na niebie się znajdujące" ${ }^{54}$. Taka wiedza była bowiem zarezerwowana dla Boga ${ }^{55}$.

Matematyka stanowiła dla niego klucz do „odczytania” świata przyrodniczego i do wiedzy pewnej. Dzięki niej charakteryzuje go optymizm poznawczy. „Takimi są właśnie czyste nauki matematyczne, a więc geometria i arytmetyka - w których rozum boży zna nieskończenie większą liczbę prawd - gdyż zna je wszystkie - jednak w tych niewielu znanych rozumowi ludzkiemu mieści się według mnie poznanie równe bożemu w obiektywnej pewności, gdyż dochodzi do zrozumienia zawartej w nich konieczności - a nie może chyba istnieć większa pewność, aniżeli właśnie ta"56. Boska wiedza była kompletna i bezpośrednia, oparta na intuicji, podczas gdy ludzka była częściowa i miała charakter dyskursywny. Jednak gdy człowiek pozna jakieś zjawiska, które zostaną wyrażone za pomocą dowodu matematycznego,

${ }^{50}$ Tenże, Trzeci list pana Galileusza do pana Marka Welsera o plamach słonecznych, [w:] T. Sierotowicz, O położeniu plam słonecznych. Literatura, dialektyka, retoryka, filozofia i astronomia $w$ Istoria e dimostrazioni intorno alle macchie solari Galileusza wraz z tłumaczeniem dzieła, Tarnów 2013, s. 461.

${ }^{51}$ Podniesienie statusu matematyki w metodologii Galileusza łączy się z odsunięciem twierdzeń teologicznych z obszaru filozofii przyrody.

${ }^{52}$ Galileusz, Waga probiercza..., dz. cyt., s. 55.

53 Por. J.C. Pitt, dz. cyt., s. 54, 60.

${ }^{54}$ Galileusz, Trzeci list..., dz. cyt., s. 397.

${ }^{55}$ Tamże, s. 398.

${ }^{56}$ Galileusz, Dialog o dwóch..., dz. cyt., s. 156. 
to rozumienie człowieka $\mathrm{w}$ tym zakresie, w obiektywnej pewności jest równe boskiemu. Jak podkreśla uczony, mimo iż „nasze poznanie [...] jest oddzielone niezmierną przepaścią od intelektu bożego" nie oznacza to, że należy nim gardzić. Galileusz uznaje ludzki umysł za jedno $\mathrm{z}$ najdoskonalszych dzieł Boga $^{57}$.

Uczony nie zaprzeczał, że Bóg może pomagać człowiekowi w poznaniu. W swoich pismach wielokrotnie używa sformułowań wskazujących, że dzięki Bożej dobroci czy łasce może dokonać danego odkrycia $^{58}$. Lecz własności natury wyrażającej się matematycznie mogą być poznane przez człowieka samego, na drodze obserwacji i obliczeń. Taka wiedza natomiast może „posłużyć jako punkt wyjścia do poprawniejszego ujęcia kwestii filozoficznych dotyczących bardziej kontrowersyjnych własności innych zjawisk przyrodniczych. Te z kolei, wznosząc ducha w stronę ostatecznego celu naszych poszukiwań, a więc w stronę Boskiego Stwórcy, pozwolą nam żywić nadzieję na poznanie w Tym, który jest źródłem światła i prawdy, każdej innej prawdy" 59 .

Stanowisko Galileusza zakłada, że umysł ludzki ma odpowiednie zdolności do poznania właściwości świata przyrodniczego, a szczególnie do zjawisk stałych i nieulegających przemianom. To jakości pierwotne, takie jak kształt, rozmiar, ruch, które mogły być wyrażone matematycznie, zostały uznane za obiektywne i istniejące realnie ${ }^{60}$. Sama istota świata wykracza poza tak sformułowany zakres i może być poznawana tylko pośrednio. Także Bóg, który według Galileusza objawia się w naturze, może być poznawany pośrednio, w tym sensie, że z obserwacji przyrody wnioskujemy o Bożej mądrości czy dobroci.

\section{Kepler}

Kepler często odwoływał się do metafory dwóch ksiąg: Pisma i Natury. Wierzył, że Bóg objawia się w obu. Zakładał też, że należy je czytać oddzielnie, co obszernie wyjaśnił we wprowadzeniu do dzieła

57 Tamże, s. 157-158.

${ }^{58}$ W Liście do Mons. Piero Diniego z 23 marca 1615 r. Galileusz pisze: „nie można wątpić w to, że Boża dobroć może od czasu do czasu wzbudzić w pokornych rozumach iskierkę swej niezmierzonej mądrości, zwłaszcza jeśli wypełnia je szczera i święta troska”, w: tenże, Listy kopernikańskie..., dz. cyt., s. 50. Por. też: tamże, s. 55. Dotyczy to szczególnie rozumienia znaczenia Pisma Świętego, ale nie tylko. Zdarza się, że uczony opisuje swoje odkrycia, wskazując na działanie łaski, jak np. w kontekście obserwacji lunetą nieba używa sformułowania „doznając z łaski Bożej olśnienia” w Sidereus nuncius..., dz. cyt., s. 34 .

59 Tenże, Trzeci list pana Galileusza..., dz. cyt., s. 398-399.

${ }^{60}$ Rozróżnienie to Galileusz precyzuje w Wadze probierczej..., dz. cyt., s. 223-228. 
Astronomia nova $(1609)^{61}$. Nie znaczy to, że Boga nie można poznawać $\mathrm{w}$ przyrodzie. Wydaje się, że w dobie sporów teologicznych to właśnie ta droga wydawała się pewniejsza. Astronomów Kepler nazywał kapłanami ${ }^{62}$. Jego praca - odkrywanie matematycznych harmonii w świecie - mogła stanowić realizacje protestanckiej zasady powszechnego kapłaństwa wiernych. Uczony wskazywał, że człowiek, różniąc się od zwierząt, jest niejako powołany do zgłębiania tajemnic Stwórcy: „Albowiem Stwórca nasz dołączył umysł do zmysłów nie tylko po to, aby człowiek podtrzymywał swój byt [...], lecz dlatego, abyśmy od zjawisk, których istnienie poznajemy zmysłami, dążyli do ustalenia przyczyn, dlaczego są i powstają, jakkolwiek nie czerpiemy z tego innych praktycznych korzyści" ${ }^{63}$.

Według Keplera, człowiek i natura byli ze sobą związani i zależni całkowicie od Boga. Tak jak świat był materialnym obrazem Boga, tak dusza człowieka była Jego niecielesnym obrazem ${ }^{64}$. Ten geometryczny wzór miał zostać przekazany człowiekowi, a jak stwierdza Kepler w Dissertatio cum Nuncio Sidereo (1610), to że człowiek ma dostęp do tego wzoru, stanowi jedną z przyczyn, dla których jest on obrazem Boga $^{65}$. Jak ukazano wcześniej, geometryczny wzór przekazany był całemu stworzeniu, które miało przestrzegać zapisanych w nim praw ${ }^{66}$. Dusza, będąc odbiciem geometrycznej Istoty Boga, miała możliwość poznawać świat przyrodniczy przez odkrywanie w nim matematycznych harmonii. Według Keplera, człowiek instynktownie ujmuje matematyczne relacje i proporcje obserwowane w rzeczach ze względu na to, że Bóg zapisał w duszy ów wzór. Świat stanowił ogniwo pośrednie między człowiekiem a Bogiem ${ }^{67}$, a celem wszelkich badań było dotarcie do matematycznego wzoru leżącego u podstaw kosmosu, ale i świata ziemskiego.

Uczony przedstawiał prawdę o świecie przez wskazanie, leżących u podstaw obserwowanych faktów, matematycznych harmonii, które ukazywały porządek tam, gdzie wcześniej go nie widziano. Czyni to bardzo wyraźnie w Harmonii świata, omawiając harmoniczne związki, które odnalazł w kosmosie. Kluczowa w tych dociekaniach była

${ }^{61}$ JKGW, t. 3, s. 28-33.

${ }^{62}$ Pisze tak w Liście do Herwarta von Hohenburga z 26 marca 1598, stwierdzając, że astronomowie są kapłanami Boga Najwyższego w odniesieniu do Księgi Natury. JKGW, t. 13, s. 193.

${ }^{63}$ J. Kepler, Tajemnica..., dz. cyt., s. 9.

${ }^{64}$ J. Kozhamthadam, dz. cyt., s. 889.

${ }^{65}$ JKGW, t. 4, s. 308.

${ }^{66}$ The Harmony of the World..., dz. cyt., s. 146 (JKGW, t. 6, s. 105).

${ }^{67}$ Por. E.W. Gerdes, dz. cyt., s. 342. 
matematyka, co implikowało wysoki jej status w jego pracach. Już na wczesnym etapie uznał tę dyscyplinę za niezbędną, gdyż pewność jej dowodów wywodziła się z badania cech ilościowych ${ }^{68}$. W ujęciu Keplera, skoro stworzenie reprezentowało wzór geometryczny, to tylko matematyka prowadziła do odkrycia istoty rzeczywistości. Konsekwencją tego było przyjęcie przez Keplera rozróżnienia na jakości pierwotne i wtórne. Te pierwsze to leżące u podstaw obserwowanego zmysłami świata matematyczne harmonie. Tylko te cechy świata, $\mathrm{w}$ odniesieniu do których otrzymujemy pewną wiedzę, ukazują nam to, co jest prawdziwe. Wiedza, którą oferuje nam umysł na podstawie danych zmysłowych, bywa sprzeczna i niejasna, więc niegodna zaufania. Jakości wtórne to tylko znaki rzeczy. Rzeczywisty świat to matematyczne harmonie odkrywane $\mathrm{w}$ rzeczach. Stąd też pewna wiedza o świecie to wiedza o jego cechach ilościowych, a umysł ludzki odpowiednio stworzony przez Boga miał możliwość ujmowania matematycznych relacji obserwowanych w świecie ${ }^{69}$. W tak ujętych relacjach człowiek dostrzegał piękno, prostotę i pewną elegancję ${ }^{70}$.

\section{Wnioski. Podobieństwa i różnice}

W podsumowaniu możemy wskazać, że obaj nowożytni uczeni przyznali wysoki status matematyce w swoich pracach, uznawali konieczność prowadzenia badań przyrodniczych niezależnie od teologii i tekstów biblijnych, obaj też sytuowali się bliżej stanowiska teologicznego intelektualistów. Jednocześnie rozwijali te założenia często w sposób odmienny. Można wskazać kilka zasadniczych różnic w podejściu do natury obu przyrodników. Według Galileusza, Bóg stworzył świat, nadał mu prawa i uznał, że świat może istnieć samodzielnie. Uczony zakładał, że natura, będąc autonomiczna wobec Boga, nie wymaga ciągłej Jego ingerencji (choć wierzył, że Bóg podtrzymuje świat w istnieniu). Dlatego nie jest konieczne, aby badając świat, stale poszukiwać w nim obecności Boga. Poznanie natury to opisanie w ka-

${ }^{68}$ Odwołania do wysokiego statusu matematyki można znaleźć w nieukończonej pracy, która powstała jeszcze przed Tajemnica kosmosu - De Quantitatibus Libelli, [w:] Joannis Kepleri Astronomi Opera Omnia, Ch. Frisch (red.), Bd. 8, Frankfurt 1870, s. 147-161. Por. też. G. Cifoletti, Kepler's De quantitatibus, „Annals of Science” 1986, vol. 43, s. 213-238.

${ }^{69}$ E. Burtt, dz. cyt., s. 55-58. Burtt przywołuje fragment z pracy De Quantitatibus..., w którym Kepler stwierdza, że tylko cechy ilościowe mogą być poznane. Tamże, s. 57.

${ }^{70}$ Kepler zwraca na to uwagę np. w Harmonii świata. W ks. V podtrzymuje przekonanie, że Bóg kierował się geometrycznym pięknem w stwarzaniu. Por. The Harmony of the World..., dz. cyt., s. 419-420. 
tegoriach matematycznych takich własności, jak kształt, rozmiar czy ruch. To one miały istnieć realnie. Poznanie naukowe miało charakter żmudnego dochodzenia do praw natury na podstawie uogólnień jednostkowych obserwacji. Galileusz odrzucał wątki animistyczne, które jawiły mu się jako nieuzasadnione naukowo.

Dla Keplera świat istniał jako odbicie Bożych wzorców. Stąd też konieczne było poszukiwanie ich w świecie, gdyż to one stanowiły o jego istocie. Zakładał więc realne istnienie świata idealnego. Poznanie natury to wskazanie matematycznych harmonii, obecnych w obserwowanych faktach. Poznanie takie zakładało dedukcję. Dla stawianych hipotez poszukiwał potwierdzenia w faktach obserwacyjnych. Kepler nie umiał zrezygnować z założenia o ciągłej aktywności Boga w świecie. Wątki animistyczne uznał za realnie istniejące i uzasadnione naukowo.

Należy zauważyć, że dla obu uczonych to matematyka stanowiła drogę poznania świata, choć koncepcja jej wykorzystania była inna. Według Galileusza, matematyka pozwalała zdobyć pewną wiedzę o własnościach tego świata, a tylko pośrednio mogła wspomagać dojście do wiedzy o istocie świata przyrodniczego. Dla Keplera wykorzystanie matematyki pozwalało na dotarcie do najgłębszej struktury świata, a nawet do Istoty Boga. Według Keplera z natury wnioskujemy nie tylko o Bożej dobroci i mądrości, ale także możemy niejako śledzić stwórczą myśl Boga.

Obaj uczeni zakładali, że naturę należy badać niezależnie od twierdzeń teologicznych, jednak pewne założenia światopoglądowe sprawiały, że naturę i możliwości jej poznania postrzegali odmiennie. Epistemologia Galileusza oparta była na przekonaniu, że człowiek w procesie poznawczym zdolny jest do realistycznego oglądu świata i jego obiektywnego opisu, w zakresie zastrzeżonym dla ludzkich kompetencji poznawczych. W epistemologię Keplera wpisane było przekonanie, że zarówno człowiek, jak i świat jest polem wszechmocnego działania Boga. Stąd też celem uczonego było odczytanie idei Bożych zawartych w świecie. W drugim modelu mniej jest miejsca na dowartościowanie ludzkiej samodzielności i zdolności poznawczych.

Na odmienne ujęcie mogła mieć wpływ formacja religijna. Stanowiska przyjęte w konfesji katolickiej i luterańskiej dotyczące porządku zbawienia wpływały na działania podejmowane w sferze badań. W wyznaniu katolickim pośrednikiem w drodze do Boga był Kościół. W wyznaniu luterańskim zrezygnowano z takiej roli Kościoła. Wiara w bliskość Boga i Jego aktywne działanie w świecie sprzyjała 
przekonaniom o możliwości bezpośredniego odkrywania Go w przyrodzie.

Jednocześnie warto zauważyć, że przywoływane w literaturze przedmiotu kategorie woluntaryzmu i intelektualizmu teologicznego oraz ich połączenie $\mathrm{z}$ empiryzmem czy racjonalizmem to problem bardzo złożony, wymykający się prostym schematom, czego przykładem są omawiani uczeni. Obaj sytuują się bliżej stanowiska intelektualistów, choć ma to inne konsekwencje w obrazie natury. W przypadku Galileusza stanowisko to sprzyja akcentowaniu regularności przyrody podtrzymywanej przez Bożą wszechmoc, z wykorzystaniem szeregu przyczyn wtórnych, a skutkuje umiejętnym uogólnianiem obserwacji i uzgadnianiu ich z teorią. Kepler, wychodząc od stanowiska intelektualistów, podkreśla całkowitą zależność stworzenia od Stwórcy oraz Bożą aktywność w świecie. Traktując Boże idee jak przyczyny celowe, ogranicza wolne działanie stworzeń, pozostawiając inicjatywę w rękach Boga i podkreślając doskonałość stwórczego planu, który może być przez człowieka poznawany.

Poglądy Galileusza prowadziły do modelu nauki charakterystycznego dla katolickich krajów w okresie oświecenia, natomiast poglądy Keplera utrzymały się w standardzie niemieckiej nauki romantycznej. Świadczy to o trwałej obecności elementów światopoglądowych w europejskim przyrodoznawstwie nowożytnym.

\title{
Summary \\ Cognitive consequences of the image of God and His omnipotence in thoughts of Galileo Galilei and Johannes Kepler
}

\begin{abstract}
This paper the role of worldview factors in shaping a different picture of the world in the thoughts of Galileo and J. Kepler. Both scholars, acknowledging the high status of mathematics, differently assessed the opportunities it offers in exploring the world. The reason for this can be seen in the different assumptions of worldviews, despite the fact, that they claimed that nature should be examined independently of theological doctrines. The scholars not only created a specific image of the world, but also interpreted it in the relation to God. They both accepted the activity of God's omnipotence in the world, but they understood it differently. This paper also refers to conception of theological voluntarism and intellectualism and their cognitive consequences mentioned in the literature.
\end{abstract}

Keywords: Galileo; J. Kepler; image of God; omnipotence 